\title{
Herbaspirillum rhizosphaerae sp. nov., isolated from rhizosphere soil of Allium victorialis var. platyphyllum
}

Correspondence Jung-Hoon Yoon jhyoon@kribb.re.kr
Seo-Youn Jung, Mi-Hwa Lee, Tae-Kwang Oh and Jung-Hoon Yoon

Korea Research Institute of Bioscience and Biotechnology (KRIBB), PO Box 115, Yusong, Taejon, South Korea

Two Gram-negative, milky-white-pigmented, motile, slightly curved rod-shaped bacterial isolates, UMS-37 ${ }^{\top}$ and UMS-40, were isolated from rhizosphere soil of wild edible greens cultivated on Ulleung island, Korea, and their taxonomic positions were investigated by a polyphasic approach. They grew optimally at $25-30{ }^{\circ} \mathrm{C}$ and contained $\mathrm{Q}-8$ as the predominant ubiquinone. The major cellular fatty acids ( $>10 \%$ of total fatty acids) were $\mathrm{C}_{16: 0}$, cyclo $\mathrm{C}_{17: 0}$ and $\mathrm{C}_{16: 1} \omega 7 \mathrm{c}$ and/or iso- $\mathrm{C}_{15: 0} 2-\mathrm{OH}$. The DNA G $+\mathrm{C}$ contents of the two isolates were 59.8 and $60.0 \mathrm{~mol} \%$. Isolates UMS-37 ${ }^{\top}$ and UMS-40 exhibited no difference in their 16S rRNA gene sequences and possessed a mean DNA-DNA relatedness level of $94 \%$; they exhibited $16 \mathrm{~S}$ rRNA gene sequence similarity levels of 96.8-98.2\% to the type strains of recognized Herbaspirillum species. Phylogenetic analyses based on 16S rRNA gene sequences showed that isolates UMS-37 ${ }^{\top}$ and UMS-40 formed a distinct phylogenetic lineage within the genus Herbaspirillum. DNA-DNA relatedness levels between isolates UMS-37 $7^{\top}$ and UMS-40 and the type strains of some phylogenetically related Herbaspirillum species were in the range 3-56\%. On the basis of differences in phenotypic properties and phylogenetic distinctiveness and genomic data, isolates UMS-37 $7^{\top}$ and UMS-40 were classified in the genus Herbaspirillum within a novel species, for which the name Herbaspirillum rhizosphaerae sp. nov. is proposed, with the type strain UMS-37 ${ }^{\top}$ $\left(=\right.$ KCTC $12558^{\top}=$ CIP $\left.108917^{\top}\right)$.
The genus Herbaspirillum, which is classified in the family Oxalobacteraceae within the Betaproteobacteria, was first described with a single species, Herbaspirillum seropedicae, that included bacterial strains associated with roots of several cereals (Baldani et al., 1986; Valverde et al., 2003). The genus accommodates bacteria that are Gram-negative, motile by means of one to three or more flagella, generally vibrioid and sometimes helical in shape (Baldani et al., 1986, 1996; Ding \& Yokota, 2004; Im et al., 2004). The genus Herbaspirillum is also characterized chemotaxonomically by having Q-8 as the predominant ubiquinone and by DNA G + C contents of 57.9-67 mol\% (Baldani et al., 1986, 1996; Kirchhof et al., 2001; Valverde et al., 2003; Ding \& Yokota, 2004; Im et al., 2004; Rothballer et al., 2006). At present, the genus consists of nine species with validly published names: $H$. seropedicae (Baldani et al., 1986), Herbaspirillum rubrisubalbicans (Baldani et al.,

The GenBank/EMBL/DDBJ accession numbers for the 16S rRNA gene sequences of isolates $U M S-37^{\top}$ and UMS-40 are respectively DQ188986 and DQ188985.

Detailed DNA-DNA hybridization results are available as supplementary material with the online version of this paper.
1996), H. frisingense (Kirchhof et al., 2001), H. lusitanum (Valverde et al., 2003), H. chlorophenolicum (Im et al., 2004), H. autotrophicum (Aragno \& Schlegel, 1978; Ding \& Yokota, 2004), H. huttiense (Leifson, 1962; Ding \& Yokota, 2004), H. putei (Ding \& Yokota, 2004) and H. hiltneri (Rothballer et al., 2006). In this study, we report on the detailed taxonomic characterization of two Gram-negative, milky-white-pigmented, slightly curved rod-shaped bacterial isolates, UMS $-37^{\mathrm{T}}$ and UMS-40, which were isolated from the rhizosphere soil of Allium victorialis var. platyphyllum, wild edible greens cultivated on Ulleung island, Korea.

Isolates UMS $-37^{\mathrm{T}}$ and UMS- 40 were isolated from the same rhizosphere soil sample of Allium victorialis var. platyphyllum using the standard dilution plating technique at $30{ }^{\circ} \mathrm{C}$ on nutrient agar (NA; Difco). To investigate their morphological, physiological and biochemical characteristics, the isolates were routinely cultivated at $30{ }^{\circ} \mathrm{C}$ on NA. Growth at various temperatures from 4 to $40{ }^{\circ} \mathrm{C}$ was measured on NA and tolerance to various $\mathrm{NaCl}$ concentrations was measured in nutrient broth (NB; Difco). Optimal $\mathrm{pH}$ and $\mathrm{pH}$ range for growth were determined in $\mathrm{NB}$ that was adjusted to various $\mathrm{pH}$ values $(\mathrm{pH} 4.5-10.5$ at intervals of $0.5 \mathrm{pH}$ units). Growth under anaerobic 
conditions was determined after incubation in an anaerobic chamber on NA and on NA supplemented with nitrate, both of which had been prepared anaerobically using nitrogen. The cell morphology and presence of flagella were examined by light microscopy (Nikon E600) and transmission electron microscopy by using cells grown on NA. The Gram reaction was determined by using the bioMérieux Gram stain kit according to the manufacturer's instructions. Catalase and oxidase activities and hydrolysis of casein, starch, hypoxanthine, xanthine, tyrosine and Tweens 20, 40, 60 and 80 were determined as described by Cowan \& Steel (1965). Hydrolysis of aesculin, gelatin and urea and nitrate reduction were studied as described by Lanyi (1987). Acid production from carbohydrates was determined as described by Leifson (1963). Utilization of various substrates for growth was determined as described by Yurkov et al. (1994). The API ZYM system (bioMérieux) was used to determine enzyme activity. Antibiotic sensitivity was tested by spreading bacterial suspension on NA and applying discs impregnated with the following antibiotics (content per disc); ampicillin $(10 \mu \mathrm{g})$, carbenicillin $(100 \mu \mathrm{g})$, cephalothin $(30 \mu \mathrm{g})$, chloramphenicol $(100 \mu \mathrm{g})$, gentamicin $(30 \mu \mathrm{g})$, lincomycin $(15 \mu \mathrm{g})$, kanamycin $(30 \mu \mathrm{g})$, neomycin $(30 \mu \mathrm{g})$, novobiocin $(5 \mu \mathrm{g})$, oleandomycin $(15 \mu \mathrm{g})$, penicillin $\mathrm{G}(20 \mathrm{U})$, polymyxin $\mathrm{B}(100 \mathrm{U})$, streptomycin $(50 \mu \mathrm{g})$ and tetracycline $(30 \mu \mathrm{g})$.

Isolates UMS- $37^{\mathrm{T}}$ and UMS-40 were cultivated for 3 days in $\mathrm{NB}$ at $30{ }^{\circ} \mathrm{C}$ to obtain the cell mass required for isoprenoid quinone analysis and DNA extraction. Isoprenoid quinones were analysed as described previously (Komagata \& Suzuki, 1987), using reversed-phase HPLC. For fatty acid methyl ester (FAME) analysis, cell mass of isolates UMS- $37^{\mathrm{T}}$ and UMS-40 was harvested from NA plates after cultivation for 3 days at $30{ }^{\circ} \mathrm{C}$. The FAMEs were extracted and prepared according to the standard protocol of the MIDI/Hewlett Packard Microbial Identification System (Sasser, 1990). Chromosomal DNA was extracted and purified by a procedure described previously (Yoon et al., 1996). The DNA G $+\mathrm{C}$ content was determined by the method of Tamaoka \& Komagata (1984) with the modification that DNA was hydrolysed and the resultant nucleotides were analysed by reversed-phase HPLC. DNA-DNA reassociation was determined by the microplate hybridization method (Ezaki et al., 1989) using photobiotin-labelled DNA probes. Type strains of eight Herbaspirillum species were used as reference strains for DNA-DNA hybridization: H. autotrophicum DSM $732^{\mathrm{T}}, H$. huttiense DSM $10281^{\mathrm{T}}$ and $H$. frisingense DSM $13128^{\mathrm{T}}$ were obtained from the Deutsche Sammlung von Mikroorganismen und Zellkulturen (DSMZ), Braunschweig, Germany; H. chlorophenolicum KCTC $12096^{\mathrm{T}}$ was obtained from the Korean Collection for Type Cultures (KCTC), Taejon, Korea, and H. hiltneri LMG $23131^{\mathrm{T}}, H$. lusitanum LMG $21710^{\mathrm{T}}$, H. rubrisubalbicans LMG $2286^{\mathrm{T}}$ and $H$. seropedicae LMG $6513^{\mathrm{T}}$ were obtained from the BCCM/LMG Bacteria Collection, Ghent University, Ghent, Belgium. 16S rRNA gene amplification was performed according to the method described previously using two universal primers (Yoon et al., 1998). Sequencing of the amplified 16S rRNA gene and phylogenetic analysis were performed as described by Yoon et al. (2003). PCR primers and conditions used to detect the nifD and nifH genes were described by Stoltzfus et al. (1997), Poly et al. (2001) and Im et al. (2004).

Morphological, cultural, physiological and biochemical characteristics of isolates UMS- $37^{\mathrm{T}}$ and UMS-40 are shown in Table 1 or are given in the species description. The isolates did not grow on semi-solid, nitrogen-free JNFb medium (Döbereiner, 1995), and nifD and nifH genes were not detected by PCR-based methods, indicating that the two isolates do not possess the ability to fix atmospheric nitrogen. The 16S rRNA gene sequences of isolates UMS$37^{\mathrm{T}}$ and UMS-40 determined in this study comprised 1488 nucleotides and were identical. Comparative 16S rRNA gene sequence analysis and estimation of phylogenetic relationships showed that isolates UMS- $37^{\mathrm{T}}$ and UMS- 40 are phylogenetically most closely related to the genus Herbaspirillum (Fig. 1). They exhibited 16S rRNA gene sequence similarity of $96.8-98.2 \%$ to the type strains of Herbaspirillum species. Sequence similarities to other species included in the phylogenetic analysis were less than $95.7 \%$. Isolates UMS- $37^{\mathrm{T}}$ and UMS-40 exhibited a mean DNA-DNA relatedness value of $94 \%$ when their DNAs were used individually as labelled DNA probes for crosshybridization. This value indicated that isolates UMS $-37^{\mathrm{T}}$ and UMS-40 are members of the same genomic species (Wayne et al., 1987). Levels of DNA-DNA relatedness between isolates UMS- $37^{\mathrm{T}}$ and UMS-40 and the type strains of eight Herbaspirillum species that showed $16 \mathrm{~S}$ rRNA gene sequence similarity values of $>97.0 \%$ to the two isolates were in the range 3-56\% (DNA-DNA relatedness levels are detailed in Supplementary Table S1 available in IJSEM Online).

The chemotaxonomic properties of isolates UMS- $37^{\mathrm{T}}$ and UMS-40 were in agreement with their phylogenetic affiliation to the genus Herbaspirillum. Isolates UMS $-37^{\mathrm{T}}$ and UMS-40 contained Q- 8 as the predominant ubiquinone, as reported for other Herbaspirillum species (Im et al., 2004; Ding \& Yokota, 2004). The cellular fatty acid profiles of isolates UMS- $37^{\mathrm{T}}$ and UMS-40 are shown in Table 2, together with those of some type strains of Herbaspirillum species. The fatty acid profiles were characterized by large amounts of straight-chain, unsaturated, hydroxy and cyclopropane fatty acids; the major components $(>10 \%$ of total fatty acids) were $\mathrm{C}_{16: 0}$, cyclo $\mathrm{C}_{17: 0}$ and $\mathrm{C}_{16: 1} \omega 7 \mathrm{c}$ and/or iso- $\mathrm{C}_{15: 0}$ 2-OH. The fatty acid profiles of two isolates were similar to those of Herbaspirillum species, although there were differences in the proportions of some fatty acids, which might be caused by different cultivation or analytical conditions (Table 2). The DNA G+C contents of isolates UMS- $37^{\mathrm{T}}$ and UMS- 40 were 60.0 and $59.8 \mathrm{~mol} \%$, respectively. The differential phenotypic properties, together with the phylogenetic distinctiveness and DNA-DNA relatedness data, provide decisive evidence that 
Table 1. Differential phenotypic characteristics of Herbaspirillum species

Strains: 1, H. rhizosphaerae sp. nov. strains UMS-37 ${ }^{\mathrm{T}}$ and UMS-40; 2, H. seropedicae LMG $6513^{\mathrm{T}}$ (unless indicated, data from Baldani et al., 1986 , 1996; Valverde et al., 2003; Im et al., 2004; Rothballer et al., 2006); 3, H. rubrisubalbicans LMG 2286 (Baldani et al., 1996; Valverde et al., 2003); 4, H. frisingense DSM $13128^{\mathrm{T}}$ (Kirchhof et al., 2001; Valverde et al., 2003); 5, H. lusitanum LMG 21710 ${ }^{\mathrm{T}}$ (Valverde et al., 2003; Rothballer et al., 2006); 6, H. chlorophenolicum KCTC $12096^{\mathrm{T}}$ (Im et al., 2004; Rothballer et al., 2006); 7, H. autotrophicum DSM 732 ${ }^{\mathrm{T}}$ (Aragno \& Schlegel, 1978; Ding \& Yokota, 2004; Rothballer et al., 2006); 8, H. huttiense DSM 10281 ${ }^{\mathrm{T}}$ (Leifson, 1962; Ding \& Yokota, 2004; Rothballer et al., 2006); 9, H. putei 7-2 ${ }^{\mathrm{T}}$ (Ding \& Yokota, 2004; Rothballer et al., 2006); 10, H. hiltneri (three strains) (Rothballer et al., 2006). +, Positive; -, negative; w, weakly positive; $\mathrm{ND}$, no data available. All strains are positive for oxidase (not determined for H. rubrisubalbicans LMG $2286^{\mathrm{T}}$ ) and leucine arylamidase. All strains are negative for lipase (C14), trypsin, $\alpha$-chymotrypsin, $\alpha$-galactosidase, $\beta$-glucuronidase, $\alpha$-glucosidase, $\beta$-glucosidase, $N$-acetyl- $\beta$-glucosaminidase, $\alpha$-mannosidase and $\alpha$-fucosidase.

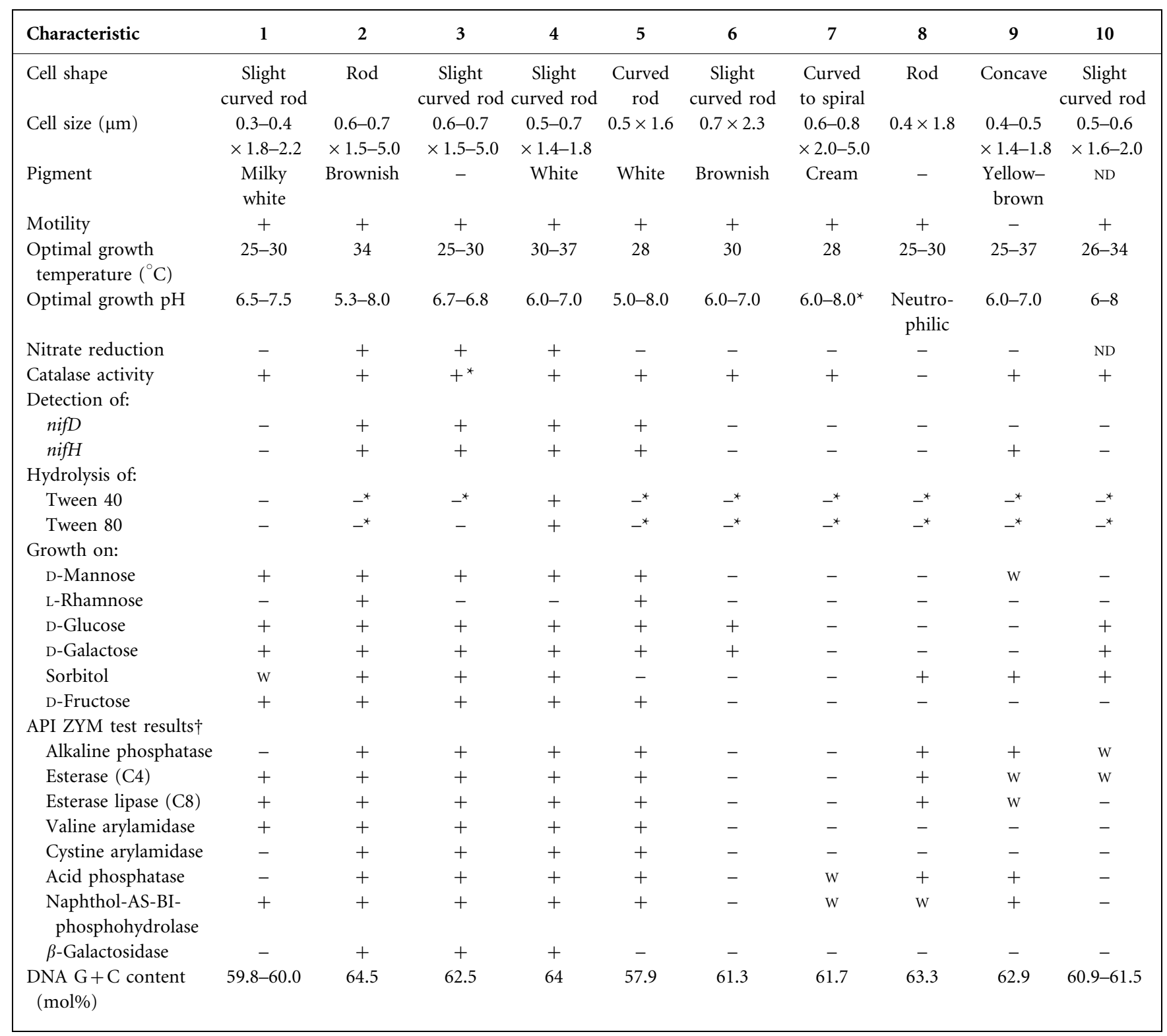

${ }^{\star}$ Data from this study.

$\dagger$ Data for the type strains of H. chlorophenolicum, H. autotrophicum, H. huttiense, H. putei and H. hiltneri from this study.

isolates UMS- $37^{\mathrm{T}}$ and UMS-40 differ from recognized Herbaspirillum species (Table 1). On the basis of the data presented, isolates UMS $-37^{\mathrm{T}}$ and UMS-40 should be classified as members of a novel species of the genus Herbaspirillum, for which the name Herbaspirillum rhizosphaerae sp. nov. is proposed. 


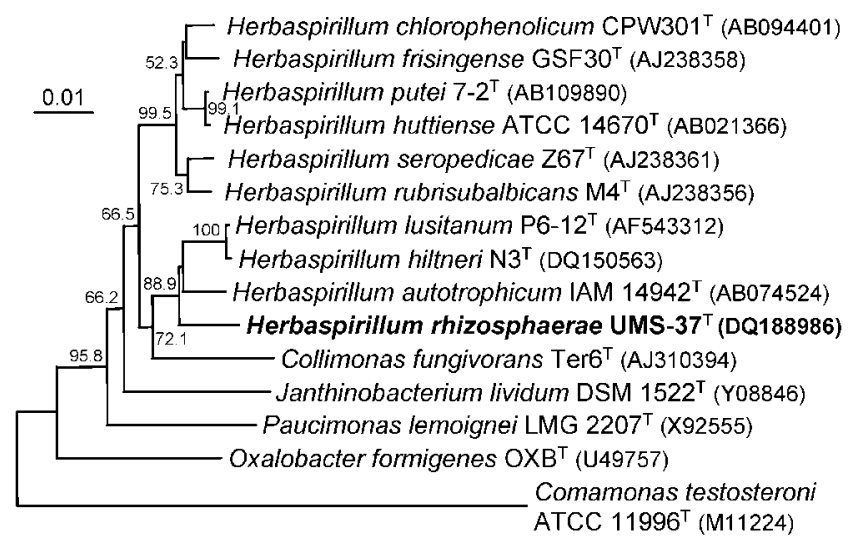

Fig. 1. Neighbour-joining tree showing the phylogenetic positions of isolates UMS-37 $7^{\top}$ and UMS-40 and other related taxa, based on 16S rRNA gene sequences. Only bootstrap values (expressed as percentages of 1000 replications) greater than $50 \%$ are shown at branching points. Comamonas testosteroni ATCC $11996^{\top}$ was used as an outgroup. Bar, 0.01 substitutions per nucleotide position.

\section{Description of Herbaspirillum rhizosphaerae sp. nov.}

Herbaspirillum rhizosphaerae (rhi.zo.sphae' rae. N.L. gen. n. rhizosphaerae of the rhizosphere).
Cells are Gram-negative, slightly curved rods, 0.3$0.4 \times 1.8-2.2 \mu \mathrm{m}$. Motile by means of bipolar flagella. No growth occurs under anaerobic conditions on NA or on NA with nitrate. Growth occurs at 4 and $34{ }^{\circ} \mathrm{C}$, with optimum growth at $25-30{ }^{\circ} \mathrm{C}$. Optimal $\mathrm{pH}$ for growth is 6.5-7.5; growth occurs weakly at pH 5.0 but not at $\mathrm{pH} 4.5$. No growth occurs in the presence of more than $3 \%(\mathrm{w} / \mathrm{v})$ $\mathrm{NaCl}$. Hypoxanthine, tyrosine and urea are hydrolysed, but aesculin, casein, gelatin, starch, xanthine and Tweens 20 and 60 are not. Acetate, citrate, glycerol, pyruvate, ribose and succinate are utilized as sole carbon and energy sources. D-Xylose is utilized, but adonitol, benzoate, Dcellobiose, formate, L-glutamate, maltose, salicin, sucrose and trehalose are not utilized. Utilization of L-malate (positive for type strain) and L-arabinose (negative for type strain) is variable. Acid is produced from D-glucose, Dgalactose, D-mannitol, D-mannose, D-ribose, D-xylose and $\mathrm{L}$-arabinose. Acid is not produced from D-cellobiose, lactose, myo-inositol, maltose, melibiose, D-melezitose, Dsorbitol, sucrose, L-rhamnose or D-raffinose. Acid production from D-fructose (positive for type strain) and trehalose (negative for type strain) is variable. Susceptible to chloramphenicol, gentamicin, kanamycin, neomycin, oleandomycin, streptomycin and tetracycline but not to ampicillin, carbenicillin, cephalothin, lincomycin, novobiocin, penicillin $G$ or polymyxin $B$. The major cellular fatty acids ( $>10 \%$ of total fatty acids) are $\mathrm{C}_{16: 0}$, cyclo $\mathrm{C}_{17: 0}$ and $\mathrm{C}_{16: 1} \omega 7 c$ and/or iso- $\mathrm{C}_{15: 0} 2-\mathrm{OH}$. The predom-

Table 2. Cellular fatty acid compositions (\%) of strains UMS- $37^{\top}$ and UMS-40 and the type strains of some Herbaspirillum species

Strains: 1, strain UMS-37 ${ }^{\mathrm{T}}$; 2, strain UMS-40; 3, H. seropedicae IAM $14977^{\mathrm{T}}$ (data from Im et al., 2004); 4, H. rubrisubalbicans IAM $14976^{\mathrm{T}}$ (Im et al., 2004); 5, H. frisingense IAM $14974^{\mathrm{T}}$ (Im et al., 2004); 6, H. chlorophenolicum $\mathrm{CPW}_{301^{\mathrm{T}}}$ (Im et al., 2004); 7, H. huttiense $\operatorname{IAM~} 14941^{\mathrm{T}}$ (Ding \& Yokota, 2004); 8, H. putei 7-2 $2^{\mathrm{T}}$ (Ding \& Yokota, 2004); 9, H. hiltneri $\mathrm{N}^{\mathrm{T}}$ (mean values of two measurements from Rothballer et al., 2006). Fatty acids that represented $<1.0 \%$ in all isolates and strains were omitted. - , Not detected/not reported.

\begin{tabular}{|c|c|c|c|c|c|c|c|c|c|}
\hline Fatty acid & 1 & 2 & 3 & 4 & 5 & 6 & 7 & 8 & 9 \\
\hline \multicolumn{10}{|l|}{ Saturated fatty acids } \\
\hline $\mathrm{C}_{12: 0}$ & 5.2 & 6.7 & 1.0 & 3.2 & 0.7 & 3.7 & 4.0 & 3.5 & - \\
\hline $\mathrm{C}_{14: 0}$ & 0.4 & 0.6 & 5.2 & 0.8 & 4.0 & 0.2 & - & 0.5 & $0.5 \pm 0.3$ \\
\hline$C_{16: 0}$ & 36.0 & 31.6 & 22.8 & 26.3 & 27.4 & 33.7 & 18.0 & 24.6 & $26.4 \pm 2.5$ \\
\hline $\mathrm{C}_{18: 0}$ & 1.2 & 1.0 & 0.6 & 1.8 & 1.7 & 2.0 & 4.0 & 1.7 & $2.7 \pm 0.3$ \\
\hline \multicolumn{10}{|c|}{ Unsaturated fatty acids } \\
\hline $\mathrm{C}_{18: 1} \omega 6 c$ & - & - & 1.9 & 2.5 & - & - & - & - & - \\
\hline $\mathrm{C}_{18: 1} \omega 7 c$ & 6.0 & 5.2 & 13.6 & 22.1 & 23.8 & 13.4 & 30.0 & 22.5 & $18.2 \pm 4.9$ \\
\hline \multicolumn{10}{|l|}{ Hydroxy fatty acids } \\
\hline $\mathrm{C}_{10: 0} 3-\mathrm{OH}$ & 1.8 & 2.1 & 1.8 & 1.4 & 1.4 & 1.3 & 1.8 & 1.6 & - \\
\hline $\mathrm{C}_{12: 0} 2-\mathrm{OH}$ & 3.7 & 5.0 & 1.8 & 0.4 & 1.1 & 2.7 & - & 0.3 & - \\
\hline $\mathrm{C}_{12: 0} 3-\mathrm{OH}$ & 4.6 & 5.5 & 4.2 & 3.1 & 3.3 & 3.3 & 3.9 & 3.3 & - \\
\hline $\mathrm{C}_{14: 0} 2-\mathrm{OH}$ & - & - & 1.6 & 2.0 & 1.1 & 0.1 & 2.8 & 2.4 & $<0.1$ \\
\hline \multicolumn{10}{|c|}{ Cyclopropane fatty acids } \\
\hline cyclo $\mathrm{C}_{17: 0}$ & 26.8 & 28.7 & 4.8 & 3.3 & 1.8 & 21.8 & 6.7 & 0.9 & $4.0 \pm 0.9$ \\
\hline cyclo $\mathrm{C}_{19: 0} \omega 8 \mathrm{c}$ & 1.5 & 1.6 & - & 0.2 & 0.1 & 1.4 & - & - & $0.1 \pm 0.1$ \\
\hline Summed feature $3^{*}$ & 12.8 & 11.1 & 39.6 & 31.7 & 32.5 & 14.9 & 28.8 & 38.0 & $44.5 \pm 1.8 \dagger$ \\
\hline
\end{tabular}

* Summed features represent groups of two or three fatty acids that could not be separated by GLC with the MIDI system. Summed features 3 contained $\mathrm{C}_{16: 1} \omega 7 c$ and/or iso- $\mathrm{C}_{15: 0} 2-\mathrm{OH}$.

$\dagger$ Data for $\mathrm{C}_{16: 1} \omega 7 c$. 
inant ubiquinone is $\mathrm{Q}-8$. The DNA $\mathrm{G}+\mathrm{C}$ content of the type strain is $60.0 \mathrm{~mol} \%$.

The type strain, UMS $-37^{\mathrm{T}} \quad\left(=\right.$ KCTC $12558^{\mathrm{T}}=\mathrm{CIP}$ $108917^{\mathrm{T}}$ ), was isolated from rhizosphere soil of Allium victorialis var. platyphyllum, wild edible greens cultivated on Ulleung island, Korea.

\section{Acknowledgements}

This work was supported by the 21C Frontier Program of Microbial Genomics and Applications (grant MG05-0401-2-0) from the Ministry of Science and Technology (MOST) of the Republic of Korea.

\section{References}

Aragno, M. \& Schlegel, H. G. (1978). Aquaspirillum autotrophicum, a new species of hydrogen-oxidizing, facultatively autotrophic bacteria. Int J Syst Bacteriol 28, 112-116.

Baldani, J. I., Baldani, V. L. D., Seldin, L. \& Döbereiner, J. (1986). Characterization of Herbaspirillum seropedicae gen. nov., sp. nov., a root-associated nitrogen-fixing bacterium. Int J Syst Bacteriol 36, 86-93.

Baldani, J. I., Pot, B., Kirchhof, G., Falsen, E., Baldani, V. L. D., Olivares, F. L., Hoste, B., Kersters, K., Hartmann, A. \& other authors (1996). Emended description of Herbaspirillum; inclusion of [Pseudomonas] rubrisubalbicans, a mild plant pathogen, as Herbaspirillum rubrisubalbicans comb. nov.; and classification of a group of clinical isolates (EF group 1) as Herbaspirillum species 3. Int J Syst Bacteriol 46, 802-810.

Cowan, S. T. \& Steel, K. J. (1965). Manual for the Identification of Medical Bacteria. London: Cambridge University Press.

Ding, L. \& Yokota, A. (2004). Proposals of Curvibacter gracilis gen. nov., sp. nov. and Herbaspirillum putei sp. nov. for bacterial isolates isolated from well water and reclassification of [Pseudomonas] huttiensis, [Pseudomonas] lanceolata, [Aquaspirillum] delicatum and [Aquaspirillum] autotrophicum as Herbaspirillum huttiense comb. nov., Curvibacter lanceolatus comb. nov., Curvibacter delicatus comb. nov. and Herbaspirillum autotrophicum comb. nov. Int J Syst Evol Microbiol 54, 2223-2230.

Döbereiner, J. (1995). Isolation and identification of aerobic nitrogen-fixing bacteria from soil and plants. In Methods in Applied Soil Microbiology and Biochemistry, pp. 134-141. Edited by K. Alef \& P. Nannipieri. London: Academic Press.

Ezaki, T., Hashimoto, Y. \& Yabuuchi, E. (1989). Fluorometric deoxyribonucleic acid-deoxyribonucleic acid hybridization in microdilution wells as an alternative to membrane filter hybridization in which radioisotopes are used to determine genetic relatedness among bacterial isolates. Int J Syst Bacteriol 39, 224-229.

Im, W.-T., Bae, H.-S., Yokota, A. \& Lee, S. T. (2004). Herbaspirillum chlorophenolicum sp. nov., a 4-chlorophenol-degrading bacterium. Int J Syst Evol Microbiol 54, 851-855.
Kirchhof, G., Eckert, B., Stoffels, M., Baldani, J. I., Reis, V. M. \& Hartmann, A. (2001). Herbaspirillum frisingense sp. nov., a new nitrogen-fixing bacterial species that occurs in C4-fibre plants. Int $J$ Syst Evol Microbiol 51, 157-168.

Komagata, K. \& Suzuki, K. (1987). Lipids and cell-wall analysis in bacterial systematics. Methods Microbiol 19, 161-207.

Lanyi, B. (1987). Classical and rapid identification methods for medically important bacteria. Methods Microbiol 19, 1-67.

Leifson, E. (1962). The bacterial flora of distilled and stored water. III. New species of the genera Corynebacterium, Flavobacterium, Spirillum and Pseudomonas. Int Bull Bacteriol Nomencl Taxon 12, 161-170.

Leifson, E. (1963). Determination of carbohydrate metabolism of marine bacteria. J Bacteriol 85, 1183-1184.

Poly, F., Monrozier, L. J. \& Bally, R. (2001). Improvement in the RFLP procedure for studying the diversity of nifH genes in communities of nitrogen fixers in soil. Res Microbiol 152, 95-103.

Rothballer, M., Schmid, M., Klein, I., Gattinger, A., Grundmann, S. \& Hartmann, A. (2006). Herbaspirillum hiltneri sp. nov., isolated from surface-sterilized wheat roots. Int J Syst Evol Microbiol 56, 1341-1348.

Sasser, M. (1990). Identification of bacteria by gas chromatography of cellular fatty acids, MIDI Technical Note 101. Newark, DE: MIDI Inc.

Stoltzfus, J. R., So, R., Malarvithi, P. P., Ladha, J. K. \& de Bruijn, F. J. (1997). Isolation of endophytic bacteria from rice and assessment of their potential for supplying rice with biologically fixed nitrogen. Plant Soil 194, 25-36.

Tamaoka, J. \& Komagata, K. (1984). Determination of DNA base composition by reversed-phase high-performance liquid chromatography. FEMS Microbiol Lett 25, 125-128.

Valverde, A., Velázquez, E., Gutiérrez, C., Cervantes, E., Ventosa, A. \& Igual, J.-M. (2003). Herbaspirillum lusitanum sp. nov., a novel nitrogen-fixing bacterium associated with root nodules of Phaseolus vulgaris. Int J Syst Evol Microbiol 53, 1979-1983.

Wayne, L. G., Brenner, D. J., Colwell, R. R., Grimont, P. A. D., Kandler, O., Krichevsky, M. I., Moore, L. H., Moore, W. E. C., Murray, R. G. E. \& other authors (1987). International Committee on Systematic Bacteriology. Report of the ad hoc committee on reconciliation of approaches to bacterial systematics. Int J Syst Bacteriol 37, 463-464.

Yoon, J.-H., Kim, H., Kim, S.-B., Kim, H.-J., Kim, W. Y., Lee, S. T., Goodfellow, M. \& Park, Y.-H. (1996). Identification of Saccharomonospora isolates by the use of genomic DNA fragments and rRNA gene probes. Int J Syst Bacteriol 46, 502-505.

Yoon, J.-H., Lee, S. T. \& Park, Y.-H. (1998). Inter- and intraspecific phylogenetic analysis of the genus Nocardioides and related taxa based on 16S rRNA sequences. Int J Syst Bacteriol 48, 187-194.

Yoon, J.-H., Kang, K. H. \& Park, Y.-H. (2003). Psychrobacter jeotgali sp. nov., isolated from jeotgal, a traditional Korean fermented seafood. Int J Syst Evol Microbiol 53, 449-454.

Yurkov, V., Stackebrandt, E., Holmes, A., Fuerst, J. A., Hugenholtz, P., Golecki, J., Gad'on, N., Gorlenko, V. M., Kompantseva, E. I. \& Drews, G. (1994). Phylogenetic positions of novel aerobic, bacteriochlorophyll $a$ containing bacteria and description of Roseococcus thiosulfatophilus gen. nov., sp. nov., Erythromicrobium ramosum gen. nov., sp. nov., and Erythrobacter litoralis sp. nov. Int J Syst Bacteriol 44, 427-434. 